\title{
JEJAK SEJARAH DALAM SASTRA LISAN DI KALIMANTAN TENGAH
}

\author{
Romein Armando \\ Email: 18101111310014@mhs.ulm.ac.id \\ Program Studi Pendidikan Sejarah Fakultas Keguruan dan Ilmu Pendidikan \\ Universitas Lambung Mangkurat \\ Banjarmasin
}

\begin{abstract}
ABSTRACK
Sastra lisan adalah karya sastra yang berbentuk ujaran. Salah satu sastra lisan di Kalimantan Tengah adalah karungut. Karungut adalah sebuah kesenian tradisional dari Kalimantan Tengah. Seni ini berupa sastra lisan atau juga bisa disebut pantun yang dilagukan. Karungut merupakan karya yang dijunjung masyarakat Dayak sebagai sastra besar klasik dan merupakan semacam pantun atau gurindam. Ada beberapa jenis dari karungut yaitu karungut cinta, karungut dongeng, karungut nasehat, karungut sansana bandar, dan karungut antang ngambun. Selain sastra lisan karungut juga sebagai sumber pembelajaran sejarah karena karungut sudah sejak dahulu dan diwariskan secara turun temurun yang disebarkan dalam bentuk lisan.
\end{abstract}

Kata Kunci : Sejarah, Kalimantan Tengah, Karungut, Suku Dayak, Jejak, Sastra, Lisan, Sumber Pembelajaran. 


\section{PENDAHULUAN}

Satra lisan merupakan sebuah karya sastra yang berkembang dalam masyarakat, yang tanpa melibatkan tulisan dalam praktiknya atau dalam kata lain, sistem pewarisannya adalah dari mulut kemulut . Sastra lisan biasa berkembang pada masyarakat yang belum mengenal tulisan atau dalam masyarakat yang sudah mengenal tulisan saat tradisi lisan sudah berkembang dalam masyarakatnya. Salah satu sastra lisan yang berkembang dimasyarakat Kalimantan Tengah salah satunya adalah Karungut. (Irawan, dkk)

Sastra yang berkembang di kalangan orang dayak umumnya berupa sastra lisan. Sastra lisan tersebut berupa nyanyian rakyat, dan upacara ritual. Masyarakat dayak juga mengenal sastra lisan, yang terlihat dalam bentuk puisi seperti deder, karungut, dan tandak, sedangkan sastra naratif berupa mite, dan legenda, berdasarkan pendapat, (Lastaria, 2017)

Karungut adalah sebuah kesenian tradisional dari Kalimantan Tengah,. Seni ini berupa sastra lisan atau juga bisa disebut pantun yang dilagukan. Karungut merupakan karya yang dijunjung masyarakat Dayak sebagai sastra besar klasik dan merupakan semacam pantun atau gurindam.

Dalam berbagai acara karungut sering di lantunkan, misalnya pada acara penyambutan tamu yang di hormati salah satu ekspresi kegembiraan dan rasa bahagia di ungkapkan dalam bentuk karungut terkadang di temukan perulangan kata pada akhir kalimat, a a a a, atau a b a b, namun terkadang juga tidak untuk mengamati cara tutur Dayak dalam ekspresikan perasaan mereka terjemahan dalam Bahasa Indonesia di buat sebagai mana adanya, kata per kata (Riwut, 2003)

Masyarakat Dayak di Kalimantan Tengah, khususnya di daerah sungai kapuas, Kahayan, rungan manuhing,Samba dan sungai Katingan mentaya dan beberapa lain sungai lain yang juga lebih mengenal lagu jenis hiburan yang mereka sebut karungut. Nyanyian tersebut berbentuk pantun yang disajikan dengan iringan musik kecapi, rebab, dan syairnya biasanya dinyanykan menurut syair yang telah ada, atau dibuat oleh seorang penyanyi secara spontan dan bisa juga menceritakan kisah seorang tokoh dan cerita nenek moyang suku Dayak. (Haryanto, 2015) 


\section{SEJARAH SINGKAT KARUNGUT}

Asal mula Karungut adalah dari Kendayu. Kendayu adalah puji-pujian/kidung dalam agama Hindu Kaharingan, oleh karena itu kadang-kadang orang mengatakan Karungut itu Kendayu atau sebaliknya Kendayu itu Karungut. Dahulu, Karungut tersebut dipakai sebagai alat oleh ibu-ibu untuk menidurkan anak-anaknya dengan cara bernyanyi dan bersenandung (Rahmawati).

seorang penduduk asli Dayak Ngaju yang menggeluti karungut sejak masih kanak-kanak, karungul berasal dari bahasa Sangiang atau bahasa Sangon 'karunya'. Fungsi karungut pad a zaman dahulu kala adalah untuk menyampaikan eerita-eerita rakyat yang mengisahkan tokoh-tokoh legendaris, sepeni tokoh Bandar, seorang tokoh super yang digambarkan sebagai manusia gagah, pandai, baik, dan mempunyai pengalaman banyak (Iper DKK, 2003)

Jenis nyanyian rakyat etnik Dayak Ngaju di Kalimantan Tengah yang diwariskan oleh nenek moyang secara lisan dalam bentuk lagu namun syairnya dapat disusun sendiri sepanjang tidak menyimpang dari Kriteria yang telah ditentukan. Karungut ialah Seni Tutur Suku Dayak Ngaju yang berisi tentang pesan-pesan moral, gambaran kehidupan, motivasi dan pesan-pesan pembangunan. Karungut juga merupakan warisan Budaya Suku Dayak Ngaju Kalimantan Tengah sebagai Warisan Budaya Dunia Non Benda yang telah diakui UNESCO Tahun 2013.

(Lestari dan Najamudin)

\section{JENIS-JENIS KARUNGUT}

Masyarakat Dayak di Kalimantan Tengah, khususnya di daerah sungai yang mengenal tradisi karungut seperti Sebagian barito,Kahayan, rungan,manuhing,samba, katingan, mentaya dan beberapa lain sungai lain yang mengenal kesenian karungut lebih mengenal lagu jenis hiburan yang mereka sebut karungut.

Nyanyian tersebut berbentuk pantun yang disajikan dengan iringan musik kecapi, rebab, dan syairnya biasanya dinyanykan menurut syair yang telah ada, atau dibuat oleh seorang penyanyi secara spontan. Menurut fungsinya bahwa karungut dibagi menjadi 5 jenis yaitu:

1. Karungut Cinta, yang liriknya berisi tentang percintaan, sanjungan atau rayuan, 
2. Karungut Dongeng, yang liriknya berisikan tentang pemujaan terhadap seorang tokoh, suatu benda atau suatu tempat yang dianggap memiliki jasa yang sangat besar terhadap masyarakat,

3. Karungut Nasehat, yang liriknya berisikan tentang nasehat-nasehat orangtua terhadap anak, guru terhadap murid, maupun generasi tua terhadap generasi muda (Haryanto, 2015).

4. Karungut Sansana Bandar, karena pada zaman dulu manusia hanya menggunakan sansana untuk memuji dan mengagungkan leluhurnya atau roh-roh sangiang (Lestari dan Najamudin).

5. Karungut Antang Ngambun dilafalkan oleh masyarakat dalam acara adat perikahan, karena di dalamnya berisikan mengenai kasih sayang dan pengorbanan. Selain dalam pernikahan, karungut Antang Ngambun juga sering dilafalkan dalam keseharian masyarakat saat bekerja atau bersantai (Irawan dan dkk).

Karungut merupakan seni khas Kalimantan Tengah yang mempunyai arti dan makna yang sangat dalam untuk ritual dan untuk menyampaikan segala sesuatu sesuai dengan keperluannya. Dahulu karangut dinyanyikan para ibu untuk menidurkan putra-putrinya (Arfianty, 2019).

\section{KETERKAITAN KARUNGUT DENGAN SUMBER PEMBELAJARAN}

Selain sebagai karya sastra lisan karungut juga dapat sebagai sumber pembelajaran bagi siswa, karena karungut bersifat turun temurun budaya bagi masyarakat Kalimantan Tengah juga sebagai jati diri di provinsi Kalimantan Tengah. Karena identitas tidak langsung menjadi melainkan melalui sebuah proses sejarah yang Panjang (Anis, 2016).

Menurut Rohani (1997:102) sumber belajar (lerning resources) dalam arti luas adalah: "segala macam sumber yang ada diluar diri seseorang (peserta didik) dan memungkinkan (memudahkan) terjadinya proses belajar (Anis, 2013).

Menurut Roestiyah (1989) sumber-sumber belajar adalah :

1. Manusia (dalam keluarga, sekolah, dan masyarakat)

2. Buku/perpustakaan

3. Media massa (majalah, surat kabar, radio, tv, dan lain-lain)

4. Lingkungan alam, sosial dan lain-lain

5. Alat pelajaran (buku pelajaran, peta, gambar,kaset, tape, papan tulis, kapur, spidol, dan lain-lain); dan 
6. Museum (tempat penyimpanan benda-benda kuno) (Anis, 2013).

Salah satu sumber pembelajaran yang dapat digunakan adalah melalui audio yaitu karungut. Karungut yang merupakan identitas budaya Kalimantan Tengah yang sejak turun temurun digunakan baik dalam acara adat, hiburan dan sumber pembelajaran.

Sejarah yang muncul dalam masyarakat merupakan sejarah yang di beredar berdasarkan sejarah lisan yang disampaikan melalui berbagai macam cara. Pesan dari Tradisi lisan berupa pesan-pesan lisan yang di ucapkan di nyanyikan atau di sebutkan di sebutkan hanya dengan alat alat musik (Anis).

Herodotus sebagai pionir dalam menulis sejarah melakukan pencarian sumber sejarah dengan melakukan wawancara dengan anak dan cucu dari pelaku perang antara Yunani dan parsi dalam arti lain, muasal karya sejarah di bangun dari sumber tradisi. Merupakan kewajaran jika Vansina mempunyai anggapan, bahwa tradisi lisan setua dengan penulisan awal sejarah (Anis, 2015) Hal itu membuktikan bahwa asal muasal sejarah yang disebarkan merupakan karya sejarah yang berbentuk lisan.

Contoh karungut tentang sejarah

Kalteng membangun

Tabe salamat salabih helu

dengan kapala kantor basupu

Pahayak karungut riwut balemu

palampang tanduk lewu Gadung Batu

artinya

salam hormat bagi terlebih dahulu dengan kepala kantor basapu

Bersama karungut angina lembut

Timbul tanduk desa gadung batu

Lime puluh uju nyelu nampara

penataan kota Palangkaraya 
Metuh Pahandut je masih desa

bapak Tjilik Riwut mendeng ngapala

\section{Artinya :}

Lima puluh tujuh tahun memulai

Penataan kota palangkaraya

Sekarang pahandut berarti masih desa

Bapak tjilik berdiri memimpin

Kemajuan kota Palangkaraya

manjadi akan tandak sarita

baton batihel uras inampa

Basusun batingkat negeri swasta

manampung pelajar dan mahasiswa

Artinya:

Kemajuan Kota Palangkaraya

Menjadikan sebuah kisah cerita

Gedung beton harus di di buat

Bersusun bertingkat negeri swasta

Menampung pelajar dan mahasiswa

Ampie huang bidang pendidikan

pelajar berprestasi are peningkatan

Jetuh nah tanda kelau jaminan

tau mambangun Kal-Teng andau rahian

Artinya:

Kelihatan di bidang pendidikan

Pelajar berprestasi banyak peningkatan

Jadi di tanda kalau jaminan 
Bisa membangun Kal-Teng hari esok

Wayah jetuh lembut sejarah

Hagatang tarung Kalimantan Tengah

Hayak kasubur petak danum itah

kakayaan alam melimpah ruah

Artinya :

Zaman Sekarang timbul sejarah

Angkat kisah Kalimantan tengah

Bersama suburnya tanah air kita

Kekayaan alam melimpah ruah

Semboyan itah je Isen Mulang

Pantang manyarah sahindai bajuang

Mudahan itah ba-umur Panjang

tikas tuh helu sarita ingarang

Artinya :

Semboyan kita yang pantang mundur

Pantang menyerah sebelum berjuang

Mudahan kita di beri umur Panjang

Sekian dari dulu cerita di karang

(seroja pulpis, 2011) 


\section{KESIMPULAN}

Satra lisan merupakan sebuah karya sastra yang berkembang dalam masyarakat, yang tanpa melibatkan tulisan dalam praktiknya atau dalam kata lain, sistem pewarisannya adalah dari mulut kemulut .

Karungut adalah sebuah kesenian tradisional dari Kalimantan Tengah. Seni ini berupa sastra lisan atau juga bisa disebut pantun yang dilagukan. Karungut merupakan karya yang dijunjung masyarakat Dayak sebagai sastra besar klasik dan merupakan semacam pantun atau gurindam. Ada beberapa jenis karungut menurut fungsinya:

karungut cinta, karungut dongeng, karungut nasehat, karungut sansana bandar, karungut antang ngambun.

Karungut bukan hanya sebagai sastra lisan tetapi karungut juga dapat menjadi sumber sejarah karena asal muasal sejarah yang disebarkan merupakan karya sejarah yang berbentuk lisan dan sudah menyebar secara turun termurun. 


\section{REFERENSI}

Anis, M. Z. A. (2013). Mewacanakan Pendidikan IPS

Anis, M. Z. A. (2015). Sejarah Bukan Warisan Melainkan Pembelajaran. Program

Studi Pendidikan Sejarah Jurusan pendidikan IPS

FKIP Universitas Lambung Mangkurat.

Anis, M. Z. A. (2016). Sejarah, Kesadaran Sejarah dan Pupusnya Identitas Nasional.

Program Studi Pendidikan Sejarah FKIP Universitas Lambung Mangkurat.

Rahmawati, N. P. R. Balai Pelestarian Nilai Budaya Kalimantan Barat

Haryanto (2015) MUSIK SUKU DAYAK Sebuah Catatan Perjalanan di Pedalaman Kalimantan

Iper Dan DKK (2003) TEMA, AMANAT, DAN NILAI BUDAYA · KARUNGUT WAJIB BELAJAR 9 TAHUN DALAM SASTRA DAYAK NGAJU

(Lestari, N. P. \& Najamudin M.) KESENIAN KARUNGUT SANSANA BANDAR SANGGAR TINGANG MENTENG PAHUNJUNG TARUNG KALIMANTAN TENGAH

(Irawan, F. Dan DKK) Makna Simbol-Simbol Budaya Dalam Karungut Antang Ngambun Bagi Kehidupan Suku Dayak Ngaju Kalimantan Tengah

(lastari, 2017) NILAI BUDAYA DALAM LEGENDA KAPUAS

(Desy arfianty, 2017)Mardin Pelestari Seni Karungut, Bertahan Hidup dari Petikan Kecapi Dayak seroja pulpis, (2011) Youtube Karungut Kal-Teng Membangun

Riwut, (2003) Maneser Panatau Tatu Hiang 